\title{
OPTIMASI PENJADWALAN PRODUKSI DI IKM ED ALUMINIUM YOGYAKARTA
}

\author{
Wildanul Isnaini ${ }^{1)}$, Andi Sudiarso ${ }^{2)}$ \\ ${ }^{1)}$ Program Studi Teknik Industri, Universitas PGRI Madiun \\ Email: wildanulisnaini@unipma.ac.id \\ ${ }^{2)}$ Program Studi Teknik Industri, Universitas Gadjah Mada \\ Email: ansoed@yahoo.co.uk
}

\begin{abstract}
ABSTRAK
Guna meningkatkan efisiensi dan efektivitas, perencanaan produksi bagi industri kecil dan menengah menjadi sesuatu yang penting karena industri tersebut memiliki lebih banyak keterbatasan dalam berbagai hal, baik material, mesin, maupun SDM. Dengan menggunakan sistem perencanaan produksi yang lebih baik, diharapkan IKM dapat meminimalisir kerugian yang mungkin akan didapatkan, tak terkecuali untuk IKM ED Aluminium. Kerugian yang mungkin didapatkan dari sistem perencanaan produksi yang kurang optimal adalah terjadinya overstock ataupun stockout yang tentu saja berimbas pada naiknya biaya atau hilangnya opportunity cost. Belum adanya sistem penjadwalan produksi yang eksak melatarbelakangi perlunya dilakukan optimasi perencanaan produksi di IKM ED Aluminium. Penelitian ini bertujuan untuk melakukan optimasi penjadwalan produksi guna menghasilkan makespan minimal dan lebih baik daripada sistem penjadwalan sebelumnya. Optimasi penjadwalan produksi dilakukan dengan metodePalmer, Algoritma Dannenbring, serta Algoritma Campbell Dudek Smith (CDS).Ketiga metode ini dipilih karena sesuai dengan proses produksi IKM ED Aluminium, yaitu flowshop. Terdapat 5 kelompok produk yang menjadi objek penelitian yaitu WB, WSD, DE, PE, dan PT. Pada penelitian ini dihasilkan metode dengan mayoritas urutan penjadwalan terbaik yaitu Algoritma CDS karena menghasilkan makespan paling minimum dengan rata-rata minimasi sebesar $33,21 \%$.
\end{abstract}

Kata kunci: Penjadwalan, Makespan, Palmer, Algoritma Dannenbring, Algoritma CDS

\section{Pendahuluan}

Perencanaan produksi bagi Industri Kecil dan Menengah (IKM) menjadi sesuatu yang penting karena industri tersebut memiliki lebih banyak keterbatasan dalam berbagai hal, baik material, mesin, maupun SDM [5]. Dengan menggunakan sistem perencanaan produksi yang lebih baik, diharapkan IKM dapat meminimalisir kerugian yang mungkin akan didapatkan. Kerugian yang mungkin didapatkan dari sistem perencanaan produksi yang kurang optimal adalah terjadinya overstock ataupun stockout. Overstock adalah kondisi dimana jumlah produksi lebih banyak daripada permintaan sehingga banyak produk yang mengendap digudang dan tidak menghasilkan uang. Sedangkanstockout adalah kondisi dimana jumlah produksi lebih sedikit dibandingkan permintaan pasar sehingga menyebabkan hilangnya opportunity cost.

ED Aluminium merupakan IKM yang awalnya bergerak dalam bidang pengecoran alat rumah tangga yang berbahan baku aluminium. Banyaknya variasi produk serta masih digunakannya intuisi dalam memperkirakan demand menyebabkan banyaknya inventori barang jadi maupun barang setengah jadi. Data stok bulan desember 2015 ED Aluminium menunjukkan adanya beberapa produk yang mengalami overstock dan ada pula beberapa produk yang hampir mengalami stockout.

Langkah pertama dalam perencanaan produksi adalah melakukan peramalan dengan tepat untuk setiap item yang akan diproduksi [1]. Hasil peramalan ini kemudian digunakan untuk menentukan jadwal produksi, mengontrol persediaan, beban tiap mesin, menentukan keperluan material handling, dan menentukan besarnya level kerja selama produksi berlangsung. Peramalan adalah sebuah metode yang menggunakan data historis untuk memprediksi kondisi masa depan [1]. Adanya perkiraan permintaan yang reliabel sebelum melakukan penjadwalan produksi dapat menghindarkan perusahaan untuk mengalami overstock atau stockout. Peramalan produksi di IKM ED Aluminimum Yogyakarta telah dilakukan pada penelitian sebelumnya [4] yang menghasilkan metode peramalan terbaik yang dapat digunakan untuk memprediksi jumlah penjualan pada bulan Januari-November 2015 yaitu: SARIMA $(3,1,1)(0,1,1)_{12}$ untuk WB, SARIMA $(1,1,1)(1,0,1)_{6}$ untuk WSD , SARIMA $(1,1,1)(1,1,0)_{6}$ untuk DE, SARIMA 


\section{KAIZEN : MANAGEMENT SYSTEMS \& INDUSTRIAL ENGINEERING JOURNAL VOL. 1 NO. 1 TEKNIK INDUSTRI UNIVERSITAS PGRI MADIUN}

$(2,1,1)(1,1,0)_{6}$ untuk PE, dan SARIMA $(2,1,3)(0,1,0)_{12}$ untuk PT. Hasil peramalan jumlah penjualan inilah yang nantinya digunakan sebagai inputan jumlah produksi yang kemudian akan diolah menjadi jadwal produksi.

Penjadwalan merupakan aspek penting pada industri manufaktur dan jasa untuk mengontrol operasi [7]. Terdapat 4 kriteria dalam pengambilan keputusan penjadwalan yaitu minimasi idle time, minimasi total waktu setup, minimasi work in process inventory, serta minimasi utilitas mesin. Penentuan jadwal yang memenuhi kriteria tersebut sangatlah sulit.Untuk menyederhanakan masalah, digunakan kriteria yang dapat mewakili beberapa kriteria tersebut yaitu minimasi makespan [2]. Minimasi makespan adalah meminimumkan waktu keseluruhan operasi proses secara lengkap. Minimasi makespan cenderung menghasilkan idle time yang pendek, persediaan barang setengah jadi yang rendah, serta utilitas mesin tinggi [2].

Berdasarkan latarbelakang yang telah dipaparkan, dalam penelitian ini akan dilakukan penelitian tentang optimasi penjadwalan serta usulan perbaikan metode penjadwalan produksi dengan parameter minimum makespan. Metode penjadwalan yang digunakan adalah metode penjadwalan yang sesuai dengan sistem produksi flowshop di IKM ED Aluminim, yaitu Palmer, Algoritma Dannenbring, serta Algoritma Campbell Dudek Smith (CDS). Penjadwalan pada sistem produksi flowshop didefinisikan sebagai penjadwalan yang dilakukan berdasarkan suatu aliran produksi, dimana mesin-mesin yang ada disusun sesuai dengan urutan proses produksinya dan setiap job harus memenuhi urutan yang sama [6].

\section{Metode Penelitian}

Penelitian ini diawali dengan melakukan studi literatur tentang penjadwalan produksi. Kemudian, dilakukan pengumpulan data berupa data jumlah produksi serta data waktu proses produksi pada masing-masing stasiun kerja.Untuk melakukan penjadwalan produksi, digunakan hasil disagregasi peramalan dari penelitian sebelumnya sebagai inputan penghitungan waktu dalam penjadwalan. Total waktu pengerjaan tersebut didapatkan dari hasil perkalian antara hasil peramalan demand produk $\mathrm{j}$ pada periode $\mathrm{n}$ dan waktu pengerjaan pada mesin $\mathrm{m}$. Setelah seluruh total waktu pengerjaan setiap produk pada tiap mesin didapatkan, selanjutnya dilakukan penjadwalan produksi.

Metode penjadwalan produksi yang digunakan pada penelitian ini adalah Palmer, Algortima Dannenbring, serta Algortima Campbell Dudek Smith (CDS). Ketiga metode ini akan menghasilkan urutan job dengan fungsi tujuan untuk meminimalkan makespan [2]. Metode-metode ini dipilih karena sesuai dengan kondisi sistem produksi di ED Aluminium yaitu melibatkan banyak variasi produk, dimana tiap produk mempunyai urutan dan melewati mesin yang sama (Flow Shop). Metode yang terbaik adalah yang menghasilkan makespan terkecil.

\section{Hasil dan Pembahasan}

Secara umum, produk-produk ED Aluminium diproses dengan urutan dan mesin yang sama. Atau, dapat dikatakan bahwa tipe produksi pada IKM tersebut adalah flowshop. Berikut adalah alur produksi di IKM ED Aluminium:

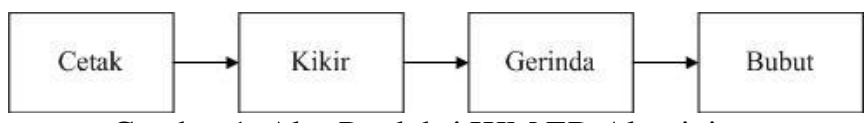

Gambar 1. Alur Produksi IKM ED Aluminium

Sebelum melakukan penjadawalan produksi, terlebih dahulu perlu dilakukan peramalan [4] untuk memprediksi jumlah penjualan produk pada tahun 2015. Hasil peramalan tersebut akan digunakan sebagai inputan jumlah produksi pada penjadwalan. Terdapat 30 produk yang akan dijadwalkan. Dari 30 produk ini, akan diagregatkan atau dikelompokkan berdasarkan family masing-masing berdasarkan harga jualnya, yaitu Wajan Biasa (WB), Wajan Super Dinar (WSD), Dandang Ekonomi (DE), Panci Ekonomi (PE), dan Panci Tasik (PT).

Hasil peramalan agregat kemudian dipecah (disagregasi) menjadi peramalan per item [4]. Disagregasi dilakukan agar hasil peramalan dapat diimplementasikan menjadi jadwal induk produksi untuk merencanakan produksi. Disagregasi peramalan dilakukan dengan metode persentase. Yaitu melihat persentase harga penjualan unit dibandingkan dengan persentase total.

Dalam penelitian ini digunakan 3 metode penjadwalan yaitu Palmer, Algoritma Dannenbring, serta Algoritma Campbell Dukdek Smith (CDS). Ketiga metode ini dipilih karena sesuai dengan sistem produksi ED Aluminium yaitu flowshop. Pada tipe penjadwalan ini, terdapat sejumlah pekerjaan (job) yang tiap-tiap job memiliki urutan 


\section{KAIZEN : MANAGEMENT SYSTEMS \& INDUSTRIAL ENGINEERING JOURNAL VOL. 1 NO. 1 TEKNIK INDUSTRI UNIVERSITAS PGRI MADIUN}

pekerjaan mesin yang sama. Atau dapat dikatakan, penjadwalan flow shop mengurutkan $\mathrm{n}$ job yang diproses dalam setiap m mesin dimana urutan mesin pada setiap jobsama dan tetap.

Hasil peramalan jumlah penjualan pada bulan Januari-November 2015 digunakan sebagai inputan data waktu untuk proses penjadwalan. Sebelum dilakukan penjadwalan menggunakan hasil peramalan, terlebih dahulu perlu dilihat apakah usulan metode dapat memperbaiki dan mempersingkat makespan. Untuk melakukan perbandingan tersebut, digunakan data historis produksi pada bulan Agustus 2015. Data historis produksi ini digunakan sebagai inputan jumlah produk yang nantinya akan menjadi total waktu produksi. Dengan cara ini, dapat dilihat apakah metode usulan menghasilkan makespan yang lebih baik atau tidak jika dibandingkan dengan aktual. Seperti yang telah disebutkan sebelumnya, produk yang akan dijadwalkan berjumlah 30 yang dibagi menjadi kelompok wajan (25 produk) dan Panci Tasik (5 produk). PT tidak dijadwalkan bersama dengan 25 produk lainnya karena PT dikerjakan dengan sistem outsourcing. Sehingga, resources yang digunakan pun berbeda.

\section{Metode Palmer}

Langkah awal untuk melakukan penjadwalan dengan metode palmer adalah menghitung total waktu proses pekerjaan $(j o b)$ pada masing-masing mesin. Total waktu proses ini didapatkan dari penjumlahan perkalian antara jumlah produk yang akan diproduksi (n) dengan waktu proses pekerjaan pada masing-masing mesin ( $\left.\mathrm{t}_{\mathrm{ij}}\right)$. Setelah itu, perlu dihitung slope index $(\mathrm{Sj})$ untuk masing-masing pekerjaan (job). Slope index. Slope index kemudian diurtkan dari yang terbesar hingga terkecil. Hasil pengurutan inilah nantinya yang akan menjadi urutan penjadwalan metode Palmer. Tabel 1 menunjukkan hasil pengurutan pekerjaan berdasarkan slope index yang sudah dihitung sebelumnya.

Tabel 1. Hasil Pengurutan Metode Palmer Berdasarkan Slope Index

\begin{tabular}{|l|c|c|l|c|c|}
\hline \multicolumn{3}{|c|}{ Sebelum di Urutkan } & \multicolumn{3}{c|}{ Setelah diurutkan } \\
\hline Produk & Slope Index & Produk & \multicolumn{2}{c|}{ Slope Index } \\
\hline Wajan Biasa 12 & S1 & -136474 & Dandang Ekonomi 28 & S19 & 71699,5 \\
\hline Wajan Biasa 13 & S2 & -119253 & Dandang Ekonomi 26 & S18 & 22089 \\
\hline Wajan Biasa 14 & S3 & -148361 & Dandang Ekonomi 45 & S23 & 20577 \\
\hline Wajan Biasa 15 & S4 & -50799 & Wajan Super Dinar 22 & S15 & $-2346,5$ \\
\hline Wajan Biasa 16 & S5 & -119401 & Panci Ekonomi 40 & S25 & -16815 \\
\hline Wajan Biasa 18 & S6 & -169940 & Wajan Super Dinar 18 & S13 & $-29101,5$ \\
\hline Wajan Biasa 20 & S7 & -118401 & Wajan Biasa 26 & S10 & -48180 \\
\hline Wajan Biasa 26 & S10 & -48180 & Wajan Biasa 15 & S4 & -50799 \\
\hline Wajan Super Dinar 15 & S11 & $-86718,7$ & Wajan Super Dinar 20 & S14 & -51968 \\
\hline Wajan Super Dinar 16 & S12 & $-65820,6$ & Wajan Super Dinar 24 & S16 & -52812 \\
\hline Wajan Super Dinar 18 & S13 & $-29101,5$ & Wajan Super Dinar 16 & S12 & $-65820,6$ \\
\hline Wajan Super Dinar 20 & S14 & -51968 & Wajan Super Dinar 15 & S11 & $-86718,7$ \\
\hline Wajan Super Dinar 22 & S15 & $-2346,5$ & Wajan Biasa 20 & S7 & -118401 \\
\hline Wajan Super Dinar 24 & S16 & -52812 & Wajan Biasa 13 & S2 & -119253 \\
\hline Dandang Ekonomi 26 & S18 & 22089 & Wajan Biasa 16 & S5 & -119401 \\
\hline Dandang Ekonomi 28 & S19 & 71699,5 & Wajan Biasa 12 & S1 & -136474 \\
\hline Dandang Ekonomi 45 & S23 & 20577 & Wajan Biasa 14 & S3 & -148361 \\
\hline Panci Ekonomi 40 & S25 & -16815 & Wajan Biasa 18 & S6 & -169940 \\
\hline
\end{tabular}

Pada bulan Agustus 2015, ED Aluminium tidak memproduksi ke 30 varian produknya. Sehingga, pada Tabel 1tertera produk-produk yang diproduksi pada bulan Agustus 2015 saja. Setelah didapatkan urutan job, kemudian dari urutan tersebut akan dihitung berapa besar makespan-nya. Dalam penelitian ini, sedikit terdapat perbedaan dengan penjadwalan-penjadwalan lainnya karena melibatkan pekerjaan mesin secara paralel. Bekerja secara paralel disini artinya mesin bekerja diwaktu yang sama dengan produk yang berbeda. Cetak mempunyai 10 stasiun yang bekerja secara paralel, kikir mempunyai 2 stasiun, gerinda mempunyai 1 stasiun, dan bubut mempunyai 9 stasiun. Adanya pekerjaan paralel ini mempengaruhi makespan yang dihasilkan. Dari perhitungan makepan yang dilakukan, metode Palmer menghasilkan makespan sebesar 24,1 hari atau $7 \%$ lebih cepat jika dibandingkan dengan proses produksi yang berjalan disistem aktual (26 hari). 


\section{KAIZEN : MANAGEMENT SYSTEMS \& INDUSTRIAL ENGINEERING JOURNAL VOL. 1 NO. 1 TEKNIK INDUSTRI UNIVERSITAS PGRI MADIUN}

\section{Algoritma Dannenbring}

Metode ini menggunakan prinsip Rapid Acces yaitu mengkombinasikan metode CDS dengan konsep slope index yang dikembangkan oleh Palmer [2]. Sama seperti metode Palmer, pada algoritma Dannenbring pun perlu dilakukan pengurutan job terlebih dahulu sebelum menghitung makespan. Perhitungan waktu proses dilakukan dengan mencari nilai $\mathrm{P}_{\mathrm{i} 1}$ dan $\mathrm{P}_{\mathrm{i} 2}$. Kemdian, $\mathrm{P}_{\mathrm{i} 1}$ dan $\mathrm{P}_{\mathrm{i} 2}$ diurutan seperti Algoritma CDS sehingga menghasilkan urutan job untuk menghitung makespan. Perhitungan makespan dapat dilihat pada Tabel 2.

Tabel 2.Makespan Metode Dannenbring Data Produksi Agustus 2015

\begin{tabular}{|c|c|c|c|c|}
\hline \multicolumn{5}{|c|}{ Makespan } \\
\hline $\begin{array}{l}\text { Produk } \\
\end{array}$ & M1 & M2 & M3 & M4 \\
\hline Wajan Biasa 20 & 184395 & 357144 & 427020 & 566772 \\
\hline Wajan Biasa 13 & 172560 & 259846,6 & 485153,9 & 587970,9 \\
\hline Wajan Biasa 16 & 135722 & 369878,6 & 495586,9 & 584922,9 \\
\hline Wajan Biasa 12 & 131768 & 460756 & 538065,9 & 599243,9 \\
\hline Wajan Biasa 14 & 143016 & 456010,6 & 589094,9 & 644919,6 \\
\hline Dandang Ekonomi 28 & 89903 & 89903 & 596649,9 & 731875,9 \\
\hline Dandang Ekonomi 45 & 104690 & 104690 & 607604,9 & 722402,9 \\
\hline Wajan Super Dinar 24 & 93236 & 531070,6 & 616205,9 & 696401,9 \\
\hline Wajan Biasa 15 & 78057 & 543849 & 638632,9 & 703060,9 \\
\hline Wajan Biasa 18 & 125990 & 621980,6 & 649012,9 & 690439,9 \\
\hline Panci Ekonomi 40 & 181677 & 181677 & 660642,9 & 750129,9 \\
\hline Wajan Super Dinar 20 & 153327 & 589497 & 679199,9 & 717935,9 \\
\hline Wajan Super Dinar 15 & 163316 & 672748,6 & 694815,5 & 719727,5 \\
\hline Wajan Super Dinar 18 & 155825 & 616337 & 701630,5 & 740966,5 \\
\hline Wajan Super Dinar 16 & 183750 & 698033,6 & 716665,5 & 734888,8 \\
\hline Wajan Biasa 26 & 179918 & 644797 & 723060,5 & 747372,5 \\
\hline Dandang Ekonomi 26 & 161768 & 161768 & 725405,5 & 766349,5 \\
\hline Wajan Super Dinar 22 & 145783 & 699257,6 & 725686,5 & 728130,5 \\
\hline \multicolumn{4}{|c|}{ Detik } & 766349,5 \\
\hline \multicolumn{4}{|c|}{ Menit } & 12772,49 \\
\hline \multicolumn{4}{|c|}{ Jam } & 212,8749 \\
\hline \multicolumn{4}{|c|}{ Hari Kerja } & 26,60936 \\
\hline
\end{tabular}

Hasil perhitugan makespan dengan Algoritma Dannenbring tidak menunjukkan nilai yang lebih baik daripada Palmer, yaitu 26,6 hari. Hasil makespan Algoritma Dannenbring melebihi makespan aktual ED Aluminium yaitu 26 hari. Namun, dengan pertimbangan bahwa nilai makespannya tidak terpaut jauh, maka Algoritma Dannenbring tetap akan digunakan dalam penjadwalan hasil peramalan.

\section{Algoritma Campbell Dudek Smith (CDS)}

Metode ketiga yang akan digunakan pada penelitian ini adalah Algoritma Campbell Dudek Smith (CDS). Metode CDS merupakan pengembangan dari algoritma Jhonson yang melakukan penjadwalan produksi berdasarkan atas waktu proses terkecil pada $\mathrm{n}$ job dan $\mathrm{m}$ mesin. Penjadwalan CDS pada penelitian ini menghasilkan 3 iterasi karena melibatkan 4 mesin. Tabel 3. menunjukkan hasil urutan pekerjaan 3 iterasi dan besar makespan yang dihasilkan.

Tabel 3. Urutan Pekerjaan dan Makespan Algoritma CDS

\begin{tabular}{|c|c|c|c|}
\hline \multirow{2}{*}{ No } & \multicolumn{3}{|c|}{ Produk } \\
\cline { 2 - 4 } & Iterai 1 & Iterasi 2 & Iterasi 3 \\
\hline 1 & Dandang Ekonomi 26 & Dandang Ekonomi 26 & Dandang Ekonomi 26 \\
\hline 2 & Dandang Ekonomi 28 & Dandang Ekonomi 28 & Dandang Ekonomi 28 \\
\hline 3 & Dandang Ekonomi 45 & Dandang Ekonomi 45 & Dandang Ekonomi 45 \\
\hline 4 & Wajan Biasa 20 & Wajan Biasa 20 & Wajan Biasa 20 \\
\hline 5 & Wajan Biasa 13 & Wajan Biasa 13 & Wajan Biasa 13 \\
\hline 6 & Wajan Biasa 16 & Wajan Biasa 14 & Wajan Biasa 16 \\
\hline 7 & Panci Ekonomi 40 & Wajan Biasa 12 & Wajan Biasa 12 \\
\hline
\end{tabular}

Copyright (C) 2018, Kaizen : Management Systems \& Industrial Engineering Journal ISSN 15222-96806 (print), ISSN 155222-95973 (online) 


\section{KAIZEN : MANAGEMENT SYSTEMS \& INDUSTRIAL ENGINEERING JOURNAL VOL. 1 NO. 1 TEKNIK INDUSTRI UNIVERSITAS PGRI MADIUN}

Tabel 3. Urutan Pekerjaan dan Makespan Algoritma CDS (Lanjutan)

\begin{tabular}{|c|c|c|c|}
\hline \multirow{2}{*}{ No } & \multicolumn{3}{|c|}{ Produk } \\
\cline { 2 - 4 } & Iterai 1 & Iterasi 2 & Iterasi 3 \\
\hline 8 & Wajan Super Dinar 24 & Wajan Biasa 16 & Wajan Biasa 14 \\
\hline 9 & Wajan Biasa 15 & Panci Ekonomi 40 & Wajan Biasa 15 \\
\hline 10 & Wajan Biasa 12 & Wajan Super Dinar 24 & Wajan Super Dinar 24 \\
\hline 11 & Wajan Biasa 14 & Wajan Biasa 15 & Wajan Biasa 18 \\
\hline 12 & Wajan Biasa 18 & Wajan Super Dinar 20 & Wajan Super Dinar 20 \\
\hline 13 & Wajan Super Dinar 18 & Wajan Biasa 18 & Panci Ekonomi 40 \\
\hline 14 & Wajan Super Dinar 20 & Wajan Super Dinar 18 & Wajan Super Dinar 15 \\
\hline 15 & Wajan Super Dinar 15 & Wajan Super Dinar 15 & Wajan Super Dinar 18 \\
\hline 16 & Wajan Biasa 26 & Wajan Super Dinar 16 & Wajan Biasa 26 \\
\hline 17 & Wajan Super Dinar 16 & Wajan Biasa 26 & Wajan Super Dinar 16 \\
\hline 18 & Wajan Super Dinar 22 & Wajan Super Dinar 22 & Wajan Super Dinar 22 \\
\hline Makespan & $\mathbf{2 5 , 5 ~ h a r i ~}$ & $\mathbf{2 5 , 9 ~ h a r i ~}$ & $\mathbf{2 3 , 6 ~ h a r i ~}$ \\
\hline
\end{tabular}

Dari Tabel 4 didapatkan urutan pekerjaan pada iterasi ke-3 menghasilkan makespan yang paling minimal, yaitu 23,6 hari atau 9\% lebih cepat daripada makespan aktual. Iterasi 1 dan 2 pun mempunyai makespan yang lebih baik daripada metode aktual. Oleh karena itu, metode Algoritma CDS pun akan disertakan untuk melakukan perhitungan makespan pada jadwal hasil peramalan.

Seperti yang telah diketahui bahwa metode usulan menghasilkan makespan yang lebih baik daripada aktual, maka 3 metode tersebut akan digunakan untuk menjadwalan produksi pada bulan Januari-November 2015. Inputan jumlah produksi yang digunakan berasal dari hasil peramalan penjualan yang telah dipaparkan sebelumnya. Dari ketiga metode ini, kemudian akan dipilih metode terbaik yang mempunyai makespan paling minimal. Metode inilah yang akan dijadikan acuan ED Aluminium untuk melakukan produksi dalam 11 bulan. Perbandingan makespanantara aktual di ED Aluminium dengan Metode Palmer, Algoritma Dannenbring, dan Algortima CDS dapat dilihat pada Tabel 4.

Tabel 4.Makespan Bulan Januari-November 2015

\begin{tabular}{|c|c|c|c|c|c|c|c|}
\hline \multirow{2}{*}{ No } & \multirow{2}{*}{ Month } & \multicolumn{6}{|c|}{ Makespan (days) } \\
\hline & & ED & Palmer & Dannenbring & CDS k=1 & CDS k=2 & CDS k=3 \\
\hline & Agustus Data Produksi & \multirow{12}{*}{26} & 24,1 & 26,6 & 25,6 & 25,9 & 23,6 \\
\hline 1 & Jan-15 & & 18,5 & 17,1 & 18,8 & 18,0 & 18,4 \\
\hline 2 & Feb-15 & & 15,5 & 13,1 & 15,2 & 15,5 & 15,8 \\
\hline 3 & Mar-15 & & 11,5 & 11,7 & 11,9 & 11,7 & 11,6 \\
\hline 4 & Apr-15 & & 13,9 & 13,1 & 14,4 & 14,0 & 14,2 \\
\hline 5 & Mei-15 & & 12,9 & 13,4 & 12,9 & 13,4 & 12,8 \\
\hline 6 & Jun-15 & & 17,3 & 16,1 & 17,1 & 15,8 & 15,7 \\
\hline 7 & Jul-15 & & 20,6 & 21,7 & 21,1 & 21,1 & 20,6 \\
\hline 8 & Agust-15 & & 21,0 & 21,4 & 21,3 & 20,6 & 21,2 \\
\hline 9 & Sep-15 & & 22,8 & 22,5 & 22,6 & 21,7 & 22,5 \\
\hline 10 & Okt-15 & & 19,07 & 22,54 & 18,69 & 18,55 & 18,59 \\
\hline 11 & Nop-15 & & 11,87 & 18,42 & 11,67 & 11,80 & 12,02 \\
\hline
\end{tabular}

Tabel 4 menunjukkan bahwa semua metode menghasilkan makespan yang lebih kecil dibandingkan dengan makespan aktual yaitu 26 hari. Metode yang menghasilkan makespan terkecil paling banyak adalah CDS yaitu 7 bulan. Jika dirata-rata, penggunaan metode penjadwalan yang eksak dapat meminimasi makespan sebesar 38,31\% dibandingkan aktual. Rincian besar minimasi makespan ditunjukkan Tabel 5. 


\section{KAIZEN : MANAGEMENT SYSTEMS \& INDUSTRIAL ENGINEERING JOURNAL VOL. 1 NO. 1 TEKNIK INDUSTRI UNIVERSITAS PGRI MADIUN}

Tabel 5.BesarMinimasi Makespan Metode Terbaik

\begin{tabular}{|c|c|c|c|c|}
\hline No & Bulan & ED & $\begin{array}{c}\text { Makespan } \\
\text { Minimum (Hari) }\end{array}$ & Besar Minimasi \\
\hline 1 & Jan-15 & 26 & 17,1 & $34,10 \%$ \\
\hline 2 & Feb-15 & 26 & 13,1 & $49,48 \%$ \\
\hline 3 & Mar-15 & 26 & 11,5 & $55,87 \%$ \\
\hline 4 & Apr-15 & 26 & 13,1 & $49,43 \%$ \\
\hline 5 & Mei-15 & 26 & 12,8 & $50,84 \%$ \\
\hline 6 & Jun-15 & 26 & 15,7 & $39,80 \%$ \\
\hline 7 & Jul-15 & 26 & 20,6 & $20,64 \%$ \\
\hline 8 & Agust-15 & 26 & 20,6 & $20,89 \%$ \\
\hline 9 & Sep-15 & 26 & 21,7 & $16,58 \%$ \\
\hline 10 & Okt-15 & 26 & 18,6 & $28,65 \%$ \\
\hline 11 & Nop-15 & 26 & 11,67 & $55,10 \%$ \\
\hline
\end{tabular}

Selain menjadwalkan 25 produk wajan, penelitian ini juga akan menjadwalkan 5 item Panci Tasik yang diproduksi secara outsourcing. Walaupun tidak dapat dibandingkan dengan kondisi aktual, karena adanya keterbatasan data, jadwal ini dapat dijadikan sebagai masukan untuk ED Aluminium. Untuk panci tasik, penjadwalan dengan makespan minimal didapatkan dengan Algoritma CDS iterasi 1.

\section{Simpulan}

Berdasarkan uraian dan hasil analisis yang dilakukan pada penelitian ini, dapat ditarik kesimpulan bahwa optimasi penjadwalan produksi terbaik di IKM ED Aluminium didapatkan dari Algoritma CDS. Hasil dari algoritma CDS menghasilkanmakespan paling minimum dengan rata-rata sebesar 33,21\%.

\section{Ucapan Terima Kasih}

Peneliti mengucapkan terima kasih atas hibah yang diberikan oleh Lembaga Penelitian dan Pengabdian Kepada Masyarakat (LPPM) Universitas PGRI Madiun sehingga penelitian ini dapat berjalan dengan lancar dan selesai tepat pada waktunya.

\section{Daftar Pustaka}

[1] Elsayed, A. dan Boucher, T., Analysis and Control of Production System,Prentice Hall International: Canada, 1994.

[2] Ginting, R., Penjadwalan Mesin, Graha Ilmu, Jawa Timur, 2009.

[3] Hanke J., dan Wichern D., Business Forecasting, Pearson Prentice Hall, New Jersey, 2005.

[4] Isnaini, W., dan Sudiarso, A., 2016, Peramalan Jumlah Permintaan Di IKM ED Aluminium Yogyakarta Menggunakan Pendekatan Kausal, Time Series, dan Gabungan Kausal-Time Series, Madiun.

[5] Kemenperin, Perencanaan Pengendalian Produksi pada Industri Kecil Menengah, 2014, retrieved from http://bdisurabaya.kemenperin.go.id on 3 Maret. 2016.

[6] Krisnawati, M., Perbandingan Performansi Algoritma Cross Entropy (CE) dan Algoritma Particle Swarm Optimization (PSO) pada Penyelesaian Permasalahan Flowhsop Scheduling, Dinamika Teknik, Vol.5, pp.53-63, 2011.

[7] Nahmias, S.,Production and Operation Analysis $3^{\text {rd }}$ ed., Irwin/McGraw-Hill,Singapore, 1997. 